Citation: G. Cappello, F. Rizzuto (2020) Journalism and fake news in the Covid-19 era. Perspectives for media education in Italy. Media Education 11(2): 3-13. doi: 10.36253/me-9682

Received: September, 2020

Accepted: October, 2020

Published: December, 2020

Copyright: @ 2020 G. Cappello, F. Rizzuto. This is an open access, peerreviewed article published by Firenze University Press (http://www.fupress. $\mathrm{com} / \mathrm{me}$ ) and distributed under the terms of the Creative Commons Attribution License, which permits unrestricted use, distribution, and reproduction in any medium, provided the original author and source are credited.

Data Availability Statement: All relevant data are within the paper and its Supporting Information files.

Competing Interests: The Author(s) declare(s) no conflict of interest.

\section{Journalism and fake news in the Covid-19 era. Perspectives for media education in Italy ${ }^{1}$}

\author{
Giornalismo e fake news nell'era del Covid-19. Prospettive per la \\ media education in Italia
}

\author{
Gianna Cappello, Francesca Rizzuto \\ Dipartimento Culture e Società, Università di Palermo \\ E-mail: gianna.cappello@unipa.it; francesca.rizzuto@unipa.it
}

\begin{abstract}
In this article, drawing from the data collected by the AGCOM during the pandemic crisis, we argue that the emergence of COVID 19 has made more evident the new relationships between the informative cybercascades, the significant need of news during a crisis, the presence of disinformation online, and the relevant consequences on collective narrations, often producing a generalized panic. We also argue that infotainment can be considered a critical turning point in the relationship between true and false in the news because of its fusion of facts, drama, and emotional narrative frames so that it is no longer possible to separate reality from media reconstruction of it. We finally argue that Media Education can help individuals unpack the complexities of this fusion and engage 'civically' so that, by combining critical thinking and social action, they can contribute to reconnect (news)media to vital issues such as credibility, freedom of expression, pluralism, democracy, and social change.
\end{abstract}

Keywords: journalism, fake news, civic engagement, infotainment, media education.

Riassunto. Attingendo ai dati raccolti dall'AGCOM durante la crisi pandemica, in questo contributo si sostiene che l'emergere del COVID 19 ha reso più evidenti le nuove relazioni tra le 'cybercascade' informative, il significativo bisogno di informazione durante una crisi, la presenza di disinformazione online e le relative conseguenze sulle narrazioni collettive, spesso producendo un panico generalizzato. Si sostiene inoltre che l'infotainment può essere considerato un punto di svolta critico nel rapporto tra vero e falso nelle notizie a causa della sua fusione di fatti, dramma e cornici narrative emotive in maniera tale da rendere sempre più difficile distinguere tra realtà e ricostruzioni mediali della stessa. Infine, si sostiene che la Media Education può aiutare il pubblico a comprendere le complessità di questa fusione e ad impegnarsi 'civicamente' in modo tale che, combinando il pensiero critico e l'azione sociale, essi possano contribuire a ricollegare l'informazione a questioni vitali come la credibilità, la libertà di espressione, il pluralismo, la democrazia e il cambiamento sociale.

Parole chiave: Giornalismo, fake news, impegno civico, infotainment, media education. 


\section{INTRODUCTION}

The emergence of COVID 19 has made more evident the new relationship between the informative cybercascades, the more significant need of news during emergencies, the presence of disinformation online and the relevant consequences on collective narrations, often producing a generalized panic. Infotainment can be also considered an important catalyser of these processes because of its fusion of facts, drama, and emotional narrative frames so that it is no longer possible to separate reality from media reconstruction of reality. This fusion warns us against any simplistic (if not ideological) view of journalism as either 'true' by definition, or, at the opposite, voluntarily deforming facts because ideologically biased. The relationship between professional journalism and reality is never obvious: points of view, interpretative frames, dramatic narratives highlight the 'artificial' nature of news reporting as a 'story'. Media Education (ME) can help individuals unpack this 'artificiality' and, when necessary, tell other stories fully expressing their 'civic engagement', hence reconnecting newsmedia to vital issues such as credibility, freedom of expression, pluralism and democracy.

\section{REDEFINING NEWS. INFOTAINMENT AND REALITY}

The centrality of the topic of fake news in the Italian information system has aroused an increasing interest among scholars, who have proposed many definitions of the different gradations of 'information disorder' (Vaccaro et al., 2019; Bracciale \& Grisolia, 2020), such as misinformation, disinformation or propaganda, focusing on the presence of manipulative, ironic or false elements in the news coverage (Riva, 2018). The evolution of this phenomenon, although linked to other open questions, such as the conceptualization of the post-truth era (Corner, 2017; Maddalena \& Gili, 2017; Lorusso, 2018), is also closely connected to two aspects which seem to characterize contemporary hybrid media ecosystem: the 'acceleration' of journalistic practices, due to the presence of digital technologies (Antenore, \& Splendore, 2017), and the success of the spectacular logic in newsmaking (Rizzuto, 2012). These aspects have brought about new informative formats, with a peculiar mix of factual and totally (or partially) false or incorrect content (Ireton \& Posetti, 2018).

Nowadays, as never before, social media's informative immediacy may offer many advantages in democratization, opening new possibilities to news access and spreading. Nevertheless, these characteristics can also become a danger both for journalism competences or legitimacy and for users' ability to recognize truthful information in the ocean of news offered by social media, most of which are without any professional control on the content.

In this article, we will argue that the emergence of COVID 19 has made more evident this new relationship between the informative cybercascades, the more significant need of news during emergencies, the presence of disinformation online as well as the relevant consequences on collective narrations, often producing a generalized panic, in a sort of communicative entropia (Bracciale \& Grisolia, 2020). Our perspective is that the news coverage of the pandemic crisis and the way individuals looked for information online made the peculiarities and the weaknesses of the Italian informative system evident. In other words, the reaction of the Italian newsmedia system and audiences to the Coronavirus global emergence shows many elements of the recent journalism crisis, due to the predominance of the spectacular frame (Thussu, 2007) and emotainment (Santos, 2009; Rizzuto, 2018) as well as to the pervasive use of digital technologies (Splendore, 2017) and the viralization process of false news (Riva, 2018).

In the Italian information system, often presented by scholars as an anomaly among Western countries (Hallin \& Mancini 2004; Rizzuto, 2009), there has always been a peculiar relationship between newsmedia and politics, considering media as means of political mobilization and using them not to inform but to participate to politics. In the last three decades, the emergence of commercial television and the success of its language and formats have made a radical change possible, bringing about a profound crisis of the social role of journalism, strongly debated by scholars (Murialdi, 2014; Morcellini, 2011).

As a consequence, the contemporary communication circuit between journalists and citizens outlines a new information ecosystem (Valentini, 2012), a framework in which there is a changed perception of the meaning of journalism itself, of its ability to 'tell stories' about real life as a serious activity connecting people to the world. A softer and more recreational use of news is privileged and imposed by infotainment, with its dramatizing and emotion-based logic, which has made more and more problematic the traditional separation between factual and false in news reporting. In this perspective, with its narrative styles and lexical choices, infotainment can be linked to the problematic topic of the increasing presence of fake news, damaging journalism and putting into crisis its social responsibility. Due to the predominance of the entertainment perspective in the selection of events and the definition of their newsworthiness, journalism tends to offer 
dramatized reconstructions of parts of reality, focusing on the visual impact of the events and the narrative strategy, too often used to confirm prejudices and stereotypes (Zelizer, 2004). Consequently, perceptions of social problems and priorities are more and more influenced by these media-narratives that are appealing but also exaggerated and distorted (Polesana, 2010; Rizzuto, 2012), since many events are selected and presented only because of their dramatic content or because images are available.

This is not a recent problem: a long time before the current debate about post-truth, in the 90 s, Geoffrey Mulgan had already underlined the main risk of entertaining news, arguing that "we now live in a world in which fantasy and reality are impossible to distinguish" (1994, p. 27). Therefore, infotainment can be considered the turning point in the relationship between true and false in the news because of its complete fusion of facts, drama, and emotional narrative frames so that it is no longer possible for the viewers to separate reality from media reconstruction of reality. According to many scholars, the increasing mix of fictional and factual reporting daily builds a biased reality, full of spectacular events, a mediated world that does not always offer a correct reconstruction of problems and issues, which is in open contrast to the ideal of journalism as an activity vital to a functioning democracy (Zelizer, 2004; Sorrentino, 2008; Mazzoleni, 2012; Rizzuto, 2018).

Moreover, journalistic processes have profoundly changed, in the last decade, due to the presence of social media: in the contemporary performative, hybrid, and convergent new media ecosystem (Boccia Artieri, 2012; Jenkins, 2013), there is a new process of growing disintermediation that not only promotes a more direct relationship between political actors and citizens, bypassing traditional mass media, but it is also transforming the newsmaking process. As never before, individuals are no longer only mere receivers of messages written by professionals in institutionalized newsrooms: they still are content consumers, but they can also become news producers and active networked citizens (Chadwick, 2013; Coleman \& Shane, 2012; Lovari, 2013). Therefore, these platforms are profoundly influencing journalism's crisis, fostering the turn from the mass media representation to the post-representation era, where the real almost vanishes, and fake news becomes quickly viral so that reality is often reduced only into its representation.

\section{LIVING IN THE INFORMATION DISORDER ERA. CORONAVIRUS AND THE NEWS IN ITALY}

In the last decades, the role played by Italian newsmedia in the perception of the difference between real and false facts has weakened due to many technological and social factors (Travaglio, 2006; Antenore \& Splendore 2017). With the spread of fake news even more so, causing an increasing interest from experts and scholars in the academic debate (Albright, 2017; Edson et al., 2017; Gili \& Maddalena, 2017).

As we noted earlier, the evolution of this phenomenon is not new. Still, it can be easily connected also to the digital 'acceleration' of journalistic practices and the informative immediacy of social media, which have been creating a digital context where false or distorted information is favoured. The lack of professional control by newsrooms in online information and the increasing viral spread of disinformation have become a cultural and political problem in the Coronavirus age, with the risk that news could have contributed to reinforcing distortions of topics such as the origin of the virus or wrong medical remedies, making invented facts as tools to interpret the world and even legitimating dangerous behaviours through specific discursive forms, narrative and rhetorical structures. In an emergence period, fake news spreads quickly, too often functioning as fuel for an information overload process, which obliges users to make unprecedented cognitive efforts for tackling enormous amounts of data.

Although fake news is currently a new definition, yet it is not a new term: this expression has existed for many centuries, but in the past decade it has shifted meaning. It is noteworthy the heterogeneity of definitions in the literature, but it is also interesting to note that what is shared across current definitions is how fake information appropriates the look of factual news and its effects. A journey through definitions might also represent, in this perspective, a recognition of news' place and role in our society, taking into account that, unlike in the past, «by misappropriating news' credibility, fake news might also undermine journalism's legitimacy, especially in a social media environment, when the actual source of information often gets removed or at least perceived at a distance» (Edson et al., 2017, p.11). All these factors are present in the definition proposed by Lazer et al. which refers to fake news as «fabricated information that mimics news media content in form but not in organizational process or intent. Fake-news outlets, in turn, lack the news media's editorial norms and processes for ensuring the accuracy and credibility of information» (2018, p.1096).

As a consequence, the category of truth as a socially perceived standard of judgment is currently weakening. On the contrary, empirical truths, often based on individual perception and construction, multiply thanks to social media. In the post-truth era, one of the conse- 
quences of this phenomenon is a progressive strengthening of impermeable ideological spheres, increasingly apart from dissent and diversity, with a dangerous shift from free and different views to many absolute individual truths, without any chance for democratic debate. According to Bracciale and Grisolia, since it is not easy to understand who can correctly be considered as responsible for disinformation, the most promising perspective is that disinformation is a 'collaborative work' where social media users may unwillingly spread partially or totally false contents (Bracciale \& Grisolia, 2020, 66). Undoubtedly, the global crisis brought about by Coronavirus has enforced some information dynamics linked to social media and made many traditional weaknesses of the Italian information system more evident.

In order to study the reaction of the Italian newsmedia system to this emergence and connect it to the recent radical changes of journalism in particular, we will analyze the data presented in the reports Osservatorio sulla disinformazione online-Speciale Coronavirus issued by AGCOM (the Italian Communication Authority) taking in considerations three months: March, April and May $2020^{2}$.

As usual, at the very start of the emergency, both information and disinformation grow: as Bracciale and Grisolia (2020) point out, already from February 21, and data by AGCOM confirm it, all media (newspapers, tv, radio, web) give an increasing space to news about the epidemic going from $4 \%$ of the total coverage (in the weeks January 1-February 20) to $45 \%$ in the period February 21-March 22 . In the following months, the news coverage trend gradually decreases: for example, if we consider the daily incidence of news about Coronavirus on total information, we see that in the last week of May (25-31), it represents $29 \%$ of the total (-2\% in comparison with the week 18-24 May and -11\% in comparison with the week 27 Apr-3 May) (AGCOM 2020, p.2). Also, the daily incidence of news about Coronavirus on total online disinformation confirms that, as days go by, the space dedicated by online disinformation sources to Coronavirus decreases, although at a less marked rate than mainstream information sources. News about Coronavirus in the week 25-31 May are 28\% of total disinformation: compared to $18-24$ May, there is $-1 \%$ and -5 $\%$ if compared to 27 Apr-3 May (AGCOM 2020, p.3).

Let us turn now to information and disinformation on Coronavirus in social networks where some interesting differences emerge: with regards to information sources, there is a continuous decrease in the space given on their social pages and accounts to news about Coronavirus; on the contrary, with regards to disinformation sources, at least in the last three weeks in May, attention to the topic maintains almost constant values
(16\% of total information sources in the week 25-31 May vs $24 \%$ of total disinformation sources in the same period) (AGCOM 2020, p.4). Starting from the end of April, the percentage of posts/tweets concerning the Coronavirus out of the total is higher for disinformation sources than for information sources. Nevertheless, compared to the most critical period of the medical crisis, in which the attention to the issue of the information component is maximum, in May, the weight of disinformation on the total news concerning the Coronavirus circulated online returns to growth, exceeding $5 \%$ earlier and reaching $6 \%$ at the end of the month (25-31 May) (AGCOM 2020, p.5).

Let us finally consider online news consumption during the coronavirus crisis. The first element that emerges is the information and disinformation boom: both the information and disinformation sites/apps recorded an increase in consumption, with values clearly above the average and those of the same period of 2019 . Internet users of the disinformation sites in March 2020 were $31 \%$ (+10\% compared to March 2019) in April 26\% of internet users compared to April 2019 ( $+5 \%$ compared to April 2019) (AGCOM 2020, p.8). In the last phase of the lockdown and throughout May 2020, when the gradual reopening of activities and travel was allowed, the media coverage of Coronavirus's issues continued to decrease progressively.

As we noted earlier, the data also confirm the great significance of emotions in Italian news coverage, as it strongly emerges during the coronavirus crisis, showing once again the centrality of emotional elements in the newsmaking logic. In the AGCOM report, emotions evoked in Italians by online news during the epidemic crisis have been analyzed through Emotional Sentiment Analysis (ESA): online news distribution for the ten emotions is obtained using a semantic analysis software (based on statistical inferences and linguistic libraries). The trend of the emotional curve in April was marked by two peaks of discontinuity: a positive one at Easter when the President of the Republic made a reassuring speech to Italians and a negative one during the difficult negotiation on European funds for economic recovery in May (AGCOM, 2020, 9).

Also, we argue that the COVID-19 pandemic has highlighted the need for reliable institutional information about the disease and the protective measures taken by the government. Data show that Italians often looked for information in institutional sites during the emergency and the reopening. Traffic on institutional sites increased with the spread of the coronavirus infection in Italy, decreasing in the last emergency period. Attention to these contents started to grow again in the weeks of 
the gradual reopening of activities and movements and subsequently diminishes (AGCOM 2020, p.15).

The last data we want to report concern the risks linked to the pandemic crisis, i.e. the massive presence of Coronavirus-related cyber-attacks in Italy and worldwide. In April, there was a considerable increase in cybersecurity threats connected to the Coronavirus and a greater diversification of attack techniques, like Trojan or Spyware. In Italy, there was a further expansion of the attack surface (target), with a varied offer of contact apps malicious tracing, attacks on video conferencing services, and the spread of traps through e-commerce sites (which contain words like 'crown' or 'COVID' in the name), particularly for the sale of pharmaceutical and biomedical products. In May, phishing campaigns and malicious apps were the most widespread types of cyber-attacks which affected, above all, sectors like research, smart working, and health, with the risk of seriously endangering the availability of services essentials to treat patients, as well as the integrity of sensitive data (AGCOM 2020, pp.18-21).

In conclusion, during the coronavirus crisis, a confused hybridization between facts and invention originated by fake news emerged making apparent a series of social risks menacing not only the journalistic profession but also the very survival of democracy, dangerously jeopardizing our social bonds, as we will argue in the next paragraphs. At the same time, however, for a better understanding of those risks, we need to overcome simplistic perspectives by which journalism is by definition either 'true' or, at the opposite, voluntarily deforming facts because ideologically biased. The relationship between professional journalism and reality is never obvious: the point of view, the way of connecting events, the logic of temporal succession of events, compared to the causative logic of the story, are just some of the elements that highlight the 'artificial' nature of news reporting as a story providing certain interpretative frames to the reader, adapting to his/her needs for readability and possible loss of attention. Media Education (ME) can help viewers unpack this 'articifiality' and find ways to reconnect newsmedia to vital issues such as credibility, freedom of expression, pluralism and democracy.

\section{FAKE NEWS AND MEDIA EDUCATION. THE RISKS OF A REDUCTIVE VISION}

The resurgence of the notion of information bias due to online fake news - especially during the Coronovirus emergency - has urged new calls for educating citizens to acquire the skills to self-govern their online behaviour responsibly. Media Education (ME) seems today to have become a priority not only, of course, for educators and teachers, but also for the general public and especially for policymakers and the industry itself. This attention is undoubtedly positive, especially in a country like Italy, where the critical study of the media has never had a coherent and systematic collocation in the school system's curricula. However, it hides many critical aspects and pitfalls, starting from the very definition of what this ME should be, as we will see (Cappello 2009, 2012).

A critical aspect (certainly not a new one) is that these calls always imply an over-dimensioning of the role of education and the media. The former is celebrated as a panacea of basically any social issue. The latter is stigmatized as a scapegoat and single cause of social problems (such as the early sexualization of childhood, youth violence, cyberbullying, fake news, and so on) that have a much more complex and multidimensional origin.

Furthermore, the educational hype resulting from the recent panic about the spreading of fake news produces a series of perverse effects (Merton 1936), which require particular attention. The first of these effects is a further strengthening of neo-liberal positions that demand a reduction of public regulation of the sector. Appealing on the one hand to the founding principles of the internet as 'naturally' uncontrollable ${ }^{3}$, and on the other to a renewed faith in the 'invisible hand' of the market, these positions actually shift the burden of responsibility onto the industry - in the form of a 'technical solutionism' (Buckingham, 2017) based on self-regulation tools such as codes of conduct, content classification systems, filters, access controls, rating systems - but above all on 'responsible' citizens.

In other words, a paradoxical situation has arisen in which support for the empowerment of the individuals through ME is inevitably coupled with a broader neoliberal dynamic that sees the transition from regulatory policies by the state (or regulatory bodies) to policies of self-governance and self-regulation by the industry, by 'responsible' parents and individuals. It is undeniably a crucial civic act to argue that we must personally take on the responsibility of becoming media educated to face the challenges posed by an increasingly technologically complex media environment. However, this move perversely produces a sort of individualistic retreat that ultimately erases any notion of the common good and collective responsibility for more systemic approaches to social issues.

Furthermore, the persistence of the digital divide (understood not so much as mere lack of access to the ${ }^{3}$ For a convincing argument against the 'mythology' of Internet uncon-
trollability, see Formenti 2008, pp. 201-216. 
'machine' but as a lack of qualified and significant competence in the use of it) reminds us that the possibility of self-empowering and critical knowledge is unevenly distributed among people (adolescents, parents, teachers) according to social stratification boundaries. As Stefano Rodotà denounced already back in the late $90 \mathrm{~s}$,

If the new media were only consumer goods, large and growing inequalities could be considered acceptable. As they are, instead, indispensable tools for cultural, social, political, and economic participation, these new inequalities become a real risk for democracy. If these problems do not become the subject of conscious policies, instead of insisting on an abstract ability of the market to solve them, there is a real risk that the information auto-roads will translate into yet another 'dead-end road' in the search for equality (1997, p.92).

The panicking hype about fake news is also producing the effect of reducing ME into a set of 'quick-fix solutions' such checklists, decalogues, and recommendations to cross-check online information, triangulate sources, verify the 'About us' section of a website, etc. Undeniably, this is useful and important, yet the question is: how much are people willing to follow checklists routinely? Moreover, supposing they are, would that be enough? We cannot define ME as a simple matter of teaching some fact-checking techniques based on rationalistic assumptions about media consumption. As the data from the AGCOM reports show, fake news is produced and circulated to appeal not to rationality but pleasure and emotion. What we trust as 'credible and true' is not necessarily always a matter of rational calculation. Indeed, ME has always had much more ambitious aims and scope that require to look at the 'bigger picture,' as we will argue in the next paragraph.

\section{FAKE NEWS AND MEDIA EDUCATION. LOOKING AT THE 'BIGGER PICTURE'}

David Buckingham opens his recent Manifesto for Media Education (2019) ${ }^{4}$ by pointing out what ME is not,

[ME] is not about using media or technology as tools, as teaching aids, or indeed as data-gathering devices. It is not about warning young people against the various forms of 'bad behavior' that media are seen to encourage. Nor is it simply about developing technical skills or providing young people with opportunities to express themselves through media (p.16).

\footnotetext{
${ }^{4}$ An Italian edition has been published in 2020 by Mondadori Università with the title Un Manifesto per la media education.
}

What is ME, then? We briefly answer this question by using fake news as an example. First of all, we need to recognize that fake news does not originate from, nor is it confined to social media only. It needs to be related, as we argued earlier, to broader changes in the media ecosystem (the turn to a spectacular logic in newsmaking being one of them), broader issues of politics and economy, and a general distrust of politicians and professional journalism. ${ }^{5}$ As Edwards and Cromwell write,

The source of fake news is not only the trollism, or the likes of Fox News, or Donald Trump, but a journalism self-appointed with false respectability, a 'liberal' journalism that claims to challenge corporate state power but in reality courts and protects it. (2018, p.xii)

Distrust against the 'Big Media' and their oligopolistic power led US journalist Dan Gillmor to predict in 2004 in his book We, the Media that social media would soon make possible for ordinary citizens to open blogs and other forms of 'citizen journalism' and produce their news. Undoubtedly, audiences have more control nowadays in shaping their media flows. However, in the ecosystem of platforms designed to network them with peers, they have ended up being forcefully encouraged to continue to share and promote ideas and ideologies relentlessly, regardless of their credibility, validity, or accuracy.

One meaningful way to counteract this trend and fully develop social media's civic potential is to shift ME towards a 'hyperlocal' civic engagement (Mihailidis, 2018). According to Mihailidis, ME scholars and practitioners can no longer assume that deconstruction and analysis skills will necessarily lead to better civic engagement. Paradoxically, critical skills seem to have led to cynicism, polarization, and distrust of mainstream news, encapsulating people into their homophilic circles where alternative (fake) news circulate, as danah boyd argues in a quite controversial article (2017). Distrust and fear of confrontation promote what Mihailidis (2018a) calls a «civic agency gap», that is a gap «between concern and capacity to act» (p.7). This gap is further encouraged by

\footnotetext{
${ }^{5} \mathrm{~A}$ recent study on trust levels in 28 countries found that while trust in institutions such as government, business, non-governmental, and media is declining, trust in peers via social media increases (Edelman 2017). Simultaneously, the report found that online echo chambers «elevate search engines over editors and reinforce personal beliefs while shutting out opposing points of view. [...] Fifty-five per cent say individuals are more believable than institutions [...]. In tandem, spontaneous speakers are more believable than those who are rehearsed, and those who are blunt and outspoken are more believable than those who are diplomatic and polite. Finally, respondents say they value personal experiences as much as, if not slightly more than, data and statistics when it comes to believability. (p.10)
} 
social networks designed to orient agency and sociality into pre-defined paths that ultimately dissuade civic engagement. While feeling self-confident and secure into their homophilic filter bubble, individuals are «uncomfortable with the prospect of being challenged in an ecosystem where comments can be vitriolic and vengeful» (p.8), hence developing a sense of apathy and distrust. To fill this gap, ME «should prioritize a civic intentionality where interventions are designed to bring people together in support of solving social problems, reinventing spaces for meaningful engagement, creating positive dialog in communities» (p.8). ${ }^{6}$

Fake news also needs to be related to the increasing commodification of the internet (fake news as clickbait are highly lucrative) and the algorithms' power to customize people's online environments trapping them into homophilic circles, as said. Research shows that, in fact, people want to remain in such circles where they can comfortably share news (no matter if fake) that appeals to their existing worldviews (hence generating more income for social media companies) (Seargeant \& Tagg, 2014). Such findings not only question long-established positions that blame the media without considering the uses (or misuses) people make of them but also highlight once again the critical role of education. In other words, the idea that algorithms are responsible for filter bubbles suggests it should be easy to fix the problem by simply getting rid of them. However, this perspective ignores how users themselves effectively create their own filter bubbles by withdrawing from political controversies and hiding opinions they disagree with.

Finally, fake news needs to be related to the fact that all media (including newsmedia) are inevitably partial. It is indeed naif, if not ideologically manipulative, to think that we can quickly and straightforwardly distinguish fake news from truth, and particularly from the mainstream newsmedia truth. As Buckingham writes,

Rather than simply spotting what's fake or fabricated, we need to be identifying the forms of bias that are present in all sources of information [...]. We need a much more sophisticated, in-depth understanding of how media (including news, in all its forms) represent the world, and how they are produced and used. We need a coherent educational strategy (2019, pp.42-43).

We need to look at all media as complex systems of signification/representation, industrial production, and social control. We need to understand why two people

\footnotetext{
6. A wide array of examples and case studies on how this civic intentionality can be developed in concrete terms can be found in the Civic Media Project.
}

who search for the same terms on their digital devices get different results; why the advertisements that appear on social profiles are different from person to person. Moreover, we need to understand why the algorithms that govern these differences are mostly invisible to ordinary users. We need to understand that they are governed by a logic that we cannot hastily settle as a purely technical question as they are in fact the result of specific choices as to what the algorithm must do, what types of data must be collected, how different data must relate to each other and, ultimately, what kind of profit (economic or political) can be done (and by whom) from these data. Paraphrasing two of Melvin Krantzberg's laws (1986), we could say that 1) the algorithm is neither good nor bad; nor is it neutral; 2) although algorithms might be a prime element in many public issues, nontechnical factors take precedence in algorithm-policy decisions.

As we know, techno-giants (such as Google or Facebook) have always defended the neutrality of their infrastructures and the freedom of expression they allow, blaming people for any incorrect, if not openly illegal, use of that freedom. In reality, as Buckingham reminds us, they «are not merely technology companies: they are also media companies. It is via the internet - and via these digital platforms and services in particular - that we are increasingly accessing media of all kinds. These companies are not merely supplying us with technical devices or tools, hardware, or software. They are also increasingly providing the means of representation and communication that are indispensable to modern life» (2019, p.13-14). As the macluhanian lesson teaches us, using one communication tool rather than another (whether new or old) inevitably implies resorting to a certain system of mediation and construction of knowledge. In this sense, all communication technologies are not 'neutral' vehicles of knowledge; they are also, inevitably, media that 'mediate' the relationship between individuals, knowledge, and power.

In the name of this presumed neutrality and the instrumentalist vulgate of the role of technological innovation in educational processes which lies behind it, techno-giants are now forcefully entering the world of education as edu-preneurs, entrepreneurs of digital education. With a philanthropic 'spirit of service', they have started equipping schools with proprietary hardware and software 'for free', training 'for free' the teachers who will use them, offering powerful tools for measuring the performance of pupils, teachers, staff. Consider, for example, the role of learning analytics and educational data science in schools and higher education, the 'cognitive classrooms' (Lytras et al., 2019), and the growing 
practical applications of computational algorithms to learning environments. All 'disruptive' transformations, indeed, that are going to change the very nature of education and deserve critical attention in the next coming years in order to understand, as Ben Williamson convincingly points out,

How digital data and the code and algorithms that constitute software are mixing with particular political agendas, commercial interests, entrepreneurial ambitions, philanthropic goals, forms of scientific expertise, and professional knowledge to create new ways of understanding, imagining and intervening in education $(2017, \text { p. } 3)^{7}$

Moreover, recently coined concepts as 'data slavery', 'dataveillance' and 'data capitalism' highlight that the price we might pay for our wired lives is personal data and the constraining of personal freedom in the interaction with techno-structures (Lupton \& Williamson, 2017; Srnicek, 2017, Zuboff, 2019).

The multifaceted nature and implications of fake news we have briefly just described well illustrate the need to adopt a view of ME as an approach that allows us to look critically at 'the bigger picture' surrounding media and our relationship with them (Buckingham 2019). This 'bigger picture' has been traditionally translated into four conceptual areas, all closely interconnected ${ }^{8}$ :

1. production, i.e., analyze the institutional and technological-industrial aspects of the media; how the growing concentration of media industries is redefining the local/global balance, national identities, or access to the media; the professional roles and routines of media production; the legislation applied to the media system, including the role of the regulatory bodies; the algorithmic logic and surveillance mechanisms that govern the collection and processing of data, etc.;

2. language, i.e., analyze the codes and conventions of media languages (their 'grammar and syntax'), reflecting on the different specific ways in which media create meaning. This implies the adoption of an analytical position that makes the familiar 'strange', that is, media texts are meticulously deconstructed in order to understand the complex processes of signification behind what goes unnoticed;

3. representation, i.e., work on one of the founding principles of media education: the media do not reflect reality but rather reproduce it according to

\footnotetext{
${ }^{7}$ See also Selwyn 2019, Pangrazio \& Selwyn 2019.

${ }^{8}$ These concepts, initially adopted in the British ME tradition, have been reframed with some variants worldwide. See NAMLE. n.d., Hobbs, 2010; Jenkins et al., 2009; UNESCO, 2016.
}

their logic and particular worldviews. By working on this area, students learn to identify stereotypes, fake news, and ultimately the subtle ways in which media representations mystify their ideology by creating the so-called 'reality effect';

4. audience, i.e., analyze how the media industry 'targets' specific audiences (by using specific language and representation choices) and how these, on the other hand, produce subjective and context-bound interpretations and uses of the media.

Let us now try and apply these key concepts to the issue of fake news. If we analyze it in terms of production, we can look at it as a form of clickbait, hence a phenomenon that is structurally implicated with the business model of social media companies. At the intersection of language and production, we could analyze its audiovisual codes and conventions comparing them with institutional and mainstream media sources; we could track particular stories looking at how they circulate across and between certain sites, and the kinds of advertising they are associated with. Fake news also raises questions about representation. As said, it would be naif (if not ideological) to claim that it is simply a question of truth versus falsehood, or that fake news is confined to social media. In fact, we need to frame it in the wider context of other forms of factual representation: all news needs to be critically analyzed and evaluated in terms of its accuracy, fairness, and objectivity (Buckingham, 2019). Finally, we can look at fake news in terms of its implications for audiences: who is particularly vulnerable to it? (Maddalena \& Gili, 2017). Why do people convincingly believe or trust fake news even if alternative versions are provided to them? What strategies do they adopt (if any) to verify fake news?

It is undoubtedly a very complex strategy that Italian teachers are often unable to tackle due to a lack of specific training. ${ }^{9}$ Therefore, unsurprisingly, if we ask today to an Italian schoolteacher what ME is, he/she will soon come up with ideas for fighting cyberbullying, fake news, videogames addiction, and online pedo-pornography. Indeed, a plethora of fragmentary and occasional educational interventions, more or less of protectionist nature, which look at these phenomena as isolated facts originating from individual deviant behaviours.

Let us close with some conclusive remarks and questions for future research.

\footnotetext{
${ }^{9}$ Unfortunately, even in the recent National Digital School Plan (Law 170 of 2015), no concrete measures are indicated to fill this lack. Apart from the promising title of one of its actions (Action \#14: A common framework for digital skills and media education for students), no definition of ME is clearly given, and hence no concrete initiatives are foreseen, including those for teacher training.
} 
While the prominence of ME goes undisputed to counteract fake news and other media-related social problems, the question is: is it enough? Most probably, it is not. It is not because you cannot overestimate - unless you are looking for an alibi - education's role as "the space where [the] huge ramifications of global capitalism are resolved» (McDougall, 2020, p.13). It is not because ME is not merely a matter of individual responsibility in becoming 'media educated' for your own sake or children's. It is also a matter of institutional responsibility in providing coherent, systematic, and well-funded programs for ME (in both formal and non-formal contexts), including in-depth teacher training (both in-service and pre-service) as well as high-quality teaching resources (including assessment and evaluation tools and methods). It is also part of this institutional responsibility to build and support partnerships with parents, civil society organizations, and the media themselves (professional journalists, for example). Finally, it is part of this institutional responsibility to find ways to regulate and reform the entire media system to stem digital capitalism's power while preserving freedom of expression, media plurality, and democracy (Cappello, 2020). Therefore, while we certainly stick to ME as key to building active digital citizenship, we also think that we

need a rebooted system of regulation that gets to grips with the complexities of media ownership in the twentyfirst century; one that encompasses top-down measures to check the dominance of individual or corporate interests as well as bottom-up measures to support genuinely independent and not-for-profit media on the ground. Above all, we need a new system of regulation that addresses both the enduring (and in many ways intensifying) grip of legacy media on the public debate; as well as the control over news and information 'flow' wielded by tech giants. (Media Reform Coalition, 2019, p.22)

\section{CONCLUSION}

In this article, we argued that during the coronavirus crisis, a confused hybridization between facts and invention originated by fake news emerged, making apparent a series of social risks menacing not only the journalistic profession but also the very survival of democracy, dangerously jeopardizing our social bonds. We also argued that to understand these risks better, we need to overcome any simplistic perspective by which journalism is either 'true' in and of itself or, at the opposite, voluntarily deforming facts because ideologically biased. The relationship between professional journalism and reality is never obvious and needs critical investigation. The Coronavirus crisis showed how dependent we are on quality media coverage and digital communications. It also showed that even if the news is not accurate, its consequences may be real, with a severe impact not only on democratic systems but also on many fields of our lives. As our findings show, during the pandemic crisis, Italians built their knowledge about it drawing from both reliable information sources and fake news. However, we also found an increase in the search for information coming from institutional sources, which gives us the possibility to think that fighting fake news, albeit difficult, is still manageable. ME is undeniably part of it, as long as, however, we do not define it as a simple matter of teaching some fact-checking techniques based on rationalistic assumptions about media consumption. We need to think of it as a complex, multidimensional approach that allows us to have a better critical understanding of the 'bigger picture' where media, fake news, and our relationship with them stand. In addition to ME, we also need to find ways to regulate the entire media system to stem digital capitalism's power while preserving freedom of expression, media plurality, and democracy.

\section{REFERENCES}

AGCOM. (2018). News vs. fake nel sistema dell informazione. https://www.agcom.it/documents/10179/12791486/ Pubblicazione+23-11-2018/93869b4f-0a8d-4380-aad2c10a0e426d83?version $=1.0$

AGCOM. (2019). Osservatorio sulla disinformazione online. https://www.agcom.it/documents/10179/15564025/ Allegato+18-7-2019+1563460522870/324d1151-d2c04271-be00-c4d59ffeaea5?version $=1.0$

AGCOM. (2020). Osservatorio sulla disinformazione Speciale Coronavirus. https://www.agcom.it/documents/10179/4691489/Allegato+14-7-2020/718e2d6d3ee3-4752-9a58-4e184d4d2924?version $=1.0$

Albright, J. (2017). Welcome to the era of fake news. Media and Communication, vol. (5)2, 87-89. http:// dx.doi.org/10.17645/mac.v5i2.977

Antenore, M., \& Splendore, S. (Eds). (2017). Data Journalism. Guida essenziale alle notizie fatte con $i$ numeri. Mondadori.

Aufderheide, P., 1993. 'Media Literacy'. A Report of the National Leadership Conference on Media Literacy. Aspen Institute.

Boccia Artieri, G. (2012). Stati di connessione. Pubblici, cittadini e consumatori nella (Social) Network Society. FrancoAngeli. 
Boyd, D. (2017). Did Media Literacy Backfire? Data \& Society. https://points.datasociety.net/did-media-literacy-backfire-7418c084d88d

Bracciale, R., \& Grisolia, F. (2020). Information disorder: acceleratori tecnologici e dinamiche sociali. Federalismi.it. https://www.federalismi.it/nv14/articolo-documento.cfm?Artid $=42112$

Buckingham, D. (2017). Fake news: is media literacy the answer? https://davidbuckingham.net/2017/01/12/ fake-news-is-media-literacy-the-answer/

Buckingham, D. (2019). Manifesto for Media Education. Polity Press.

Cappello, G. (2012). Ritorno al futuro. Miti e realtà dei nativi digitali. Aracne.

Cappello, G. (2017). Literacy, Media Literacy and Social Change. Where Do We Go From Now? Italian Journal of Sociology of Education, 9(1), 31-44. https://doi. org/10.14658/pupj-ijse-2017-1-3

Cappello, G. (2020). La media education a scuola. Un approccio olistico per la costruzione della cittadinanza digitale. In D. Buckingham. Manifesto per la media education (pp. VII-XVIII). Mondadori Università.

Chadwick, A. (2013). The Hybrid Media System: Politics and Power. Oxford University Press.

Coleman, S., \& Shane, P.M. (2012). Connecting democracy. Online consultation and the Flow of Political Communication. MIT Press.

Corner, J. (2017). Fake news, post-truth and media-political change. Media, Culture \& Society, 39(7), 11001107. https://doi.org/10.1177/0163443717726743

Edelman. 2017. Trust Barometer - 2017 Annual Global Study. Executive Summary. https://bit.ly/3lR2csJ

Edson, C., Tandoc Jr., Lim Z.W, Ling R. (2018). Defining Fake news. Digital Journalism, 6(2), 137 -153. https:// doi.org/10.1080/21670811.2017.1360143

Formenti, C. (2008). Cybersoviet. Utopie postdemocratiche e nuovi media. Raffaello Cortina.

Hallin, D., \& Mancini, P. (2004). Modelli di giornalismo. Laterza.

Hobbs, R. (2010). Digital and Media Literacy: A Plan of Action. The Aspen Institute.

Kranzberg, M. (1986). Technology and History: 'Kranzbergs Laws'. Technology and Culture. 27(3): 544-560. https://doi.org/10.2307/3105385

Jenkins, H., R. Purushotma, M. Weigel, K. Clinton, \& A. J. Robison. (2009). Confronting the Challenges of Participatory Culture: Media Education for the 21st century. MIT Press.

Ireton, C., Posetti, J. (Eds) (2018), Journalism, 'Fake News' \& Disinformation. UNESCO.

Lazer, D. M., Baum, M.A., Benkler, Y., Berinsky, A. J., Greenhill, K. M, Menczer, F. \& Schudson, M. (2018),
The science of fake news. Science, 359(6380), 10941096. https://scholar.harvard.edu/files/mbaum/files/ science_of_fake_news.pdf

Lupton, D., \& Williamson, B. (2017). The datafied child: The dataveillance of children and implications for their rights. New Media \& Society, 19(5), 780-794. https://doi.org/10.1177/1461444816686328

Lytras, M.D., Aljohani, N., Daniela, L. \& Visvizi, A. (2019). Cognitive Computing in Technology-Enhanced Learning, IGI Global.

Lorusso, A. M. (2018). Postverità. Fra reality tv, social media e storytelling. Laterza.

Lovari, A. (2013). Networked citizens. Comunicazione pubblica e amministrazioni digitali. Franco Angeli.

Maddalena, G. \& Gili, G., (2017). Chi ha paura della postverità? Effetti collaterali di una parabola culturale. Marietti.

Mazzoleni, G. (2012). La comunicazione politica. Il Mulino.

McDougall, J. (2020). Fake News vs. Media Studies. Travels in a False Binary. Palgrave McMillan.

Media Coalition Reform (2019). Who Owns the UK Media? https://www.mediareform.org.uk/wp-content/ uploads/2019/03/FINALonline2.pdf

Mihailidis, P. (2018). Civic Media Literacies: Re-imagining Human Connection in an Age of Digital Abundance. Routledge.

Mihailidis, P. (2018a). Civic media literacies: re-Imagining engagement for civic intentionality. Learning Media and Technology, (43)2, 1-13. https://doi.org/10. 1080/17439884.2018.1428623

Morcellini, M. (ed.). (2011). Neogiornalismi. Tra crisi e rete. Come cambia il sistema dell'informazione. Mondadori.

Mulgan, G. (1994). Politics in an Antipolitical Age. Polity Press.

Murialdi, P. (2014). Storia del giornalismo italiano. Dalle gazzette a Internet. Il Mulino.

NAMLE. n.d. Media Literacy Defined. https://namle.net/ publications/media-literacy-definitions/.

Pangrazio, L., \& Selwyn, N. (2019). 'Personal data literacies': A critical literacies approach to enhancing understandings of personal digital data. New Media \& Society, 21(2), 419-437. https://doi. org/10.1177/1461444818799523

Polesana, M.A. (2010). Criminality show. La costruzione mediatica del colpevole. Carocci.

Riva, G. (2018). Fake news. Il Mulino.

Rizzuto, F. (2009). Giornalismo e democrazia. L'informazione politica in Italia. Palumbo.

Rizzuto, F. (2012). Lo spettacolo delle notizie. Aracne.

Rizzuto, F. (2018). La società dell'orrore. Terrorismo e comunicazione nellera del giornalismo emotivo. Pisa University Press. 
Santos, J. (2009). Daring to feel. Violence, the Newsmedia and their Emotions. Lexington Books.

Seargeant, P. \& Tagg, C. (Eds) (2014). The Language of Social Media. Identity and Community on the Internet, Palgrave Macmillan.

Selwyn, N. (2019). What's the Problem with Learning Analytics?. Journal of Learning Analytics, 6(3), 11-19. https://doi.org/10.18608/jla.2019.63.3.

Srnicek, S. (2017). Platform Capitalism. Polity Press.

Sorrentino, C. (2008). La società densa. Riflessioni intorno alle nuove forme di sfera pubblica. Le Lettere.

Splendore, S. (2017). Il giornalismo ibrido. Come cambia la cultura giornalistica in Italia. Carocci.

Thussu, D.K.(2007). News as Entertainment: The Rise of Global Infotainment. Sage.

Travaglio, M. (2006). La scomparsa dei fatti. Il Saggiatore.

Vaccaro, S., Rizzuto, F. \& Brancato, G. (eds). (2019), La Comunicazione alla sfida della (dis)informazione. Aracne.

UNESCO. (2016). Media and Information Literacy: Reinforcing Human Rights, Countering Radicalization and Extremism. http://www.unesco.org/new/en/communication-and-information/media-development/ media-literacy/five-laws-of-mil/

Valentini, E. (2012). Dalle gazzette alliPad. Mondadori.

Zelizer, B. (2004). Taking journalism seriously. Sage.

Zuboff, S. (2019). The Age of Surveillance Capitalism: The Fight for a Human Future at the New Frontier of Power. Profile Books. 